\title{
Predation follows competition in depth selection behaviour of Cladocera in a deep lake (E Poland)
}

\author{
MAŁGORZATA ADAMCZUK \\ Department of Hydrobiology, University of Life Sciences, Dobrzańskiego 37, \\ Lublin 20-262, Poland; e-mail: malgorzata.adamczuk@up.lublin.pl
}

(Received on 18 December 2008; Accepted on 07 August 2009)

\begin{abstract}
Observations of the vertical distribution of Cladocera in the pelagic zone of the deep Lake Piaseczno (38.8 m) focused on 6 species: Diaphanosoma brachyurum, Daphnia longispina, D. cucullata, Bosmina coregoni, B. longirostris, and Chydorus sphaericus. The animals displayed clear depth preferences, and their migration patterns were limited to small depth amplitudes. The results show that vertical habitat segregation of cladocerans in the lake consists mostly in the mechanism of competition for accessible food resources, rather than in the mechanism of predation avoidance.
\end{abstract}

Keywords: diel vertical migration, vertical distribution, Cladocera, interspecific competition

\section{INTRODUCTION}

Cladocerans are an important component of freshwater ecosystems. For decades they have been of interest to researchers because of their curious ecology, especially their vertical migrations. Several kinds of migrations are distinguished. Very common and well reported in literature are normal (nocturnal) migrations, when a population resides deeper in the water column during the day than during the night (Cushing 1951). Reverse migrations, when populations reside deeper during the night than during the day (Bayly 1986, Ohman 1990) are less common. Another type of depth selection behaviour consists in a very distinct vertical distribution of a species, although the population does not show any diel vertical migrations (Pijanowska \& Dawidowicz 1987). In the research carried so far, numerous environmental factors, both biotic and abiotic, seemed to be responsible for vertical distribution of cladocerans. They all can be divided into: (1) direct cues, like temperature and oxygen concentration (Wright \& Shapir o 1990), distribution of nutrients in the water column (Kit chell et. al 1979), and solar radiation (Ringel ber g 1999); and (2) evolutionarily conditioned forces, like pressure of planktivorous fish (St ich \& Lampert 1981, Gl iwicz 1986) and presence of kairomones and other alarm substances (Ringel berg et al. 1991). However, it is 
considered that a combination of two major factors - fish predation and food satiation - is most strongly related to cladoceran vertical migrations. The former consists in that cladocerans avoid planktivorous fish in time and space. The latter results from the fact that food resources are not uniformly distributed in the water column, and cladocerans tend to gather in the layers with the most suitable food resources. The aim of this study was to find behavioural causes of diel vertical distribution patterns of cladoceran species in the pelagic zone of a deep mesotrophic lake.

\section{MATERIAL AND METHODS}

The study was performed in a dimictic Lake Piaseczno located in the ŁęcznaWłodawa Lakeland (in eastern Poland). This lake is deep (38.8 $\mathrm{m}$ ) and covers 84.7 ha. Water samples were taken in the vertical profile in the deepest part of the lake during the summer stratification period. Cladocerans were collected from the water column over the 3 daily cycles, 4 times within every cycle, including dawn, day, dusk and night periods. Material was taken from the epilimnion $(0,1,3 \mathrm{~m})$, metalimnion $(5,7$, $9 \mathrm{~m})$ and hypolimnion $(11,13,15,20,25,35 \mathrm{~m})$. Duplicate samples were collected with a 5-litre sampler, sieved through a $55-\mu \mathrm{m}$ mesh net and preserved in formalin and glycerine solution. At the same time, temperature and oxygen concentration were measured in the whole vertical profile.

In the laboratory, cladocerans were enumerated and identified to species level. The number of individuals per $1 \mathrm{dm}^{3}$ of water was calculated for each sample. Depth selection was compared for 6 species: Diaphanosoma brachyurum (Liévin, 1848), Daphnia longispina O. F. Müller, 1785, Daphnia cucullata Sars, 1862, Bosmina coregoni Baird, 1857, Bosmina longirostris (O. F. Müller, 1785) and Chydorus sphaericus (O. F. Müller, 1785). The mean residence depth (MRD) was estimated for each species, according to the Frost \& BOLLENS' (1992) equation:

$$
M R D=\frac{\sum_{i}\left(n_{i} \cdot d_{i}\right)}{\sum_{i} n_{i}}
$$

where $n_{i}$ is the abundance (ind $\cdot \mathrm{dm}^{-3}$ ) at depth $i\left(d_{i}\right)$. MRD values allowed to evaluate vertical migration patterns of the examined species.

The ANOVA Friedman test was used to determine the effect of site and time on the distribution of the cladoceran community.

\section{RESULTS}

At the depth of 0-5 m, water temperature was mostly between $21^{\circ} \mathrm{C}$ and $23^{\circ} \mathrm{C}$. The thermocline was at the depth of 5-9 m, so that water temperature reached $8-10^{\circ} \mathrm{C}$ at the depth of $11 \mathrm{~m}$, and thereafter decreased steadily. The concentration of dissolved oxygen in the epilimnion was $6-8 \mathrm{mg} \cdot \mathrm{dm}^{-3}(63-88 \%)$. Its maximum was at the depth of $7-11 \mathrm{~m}$ at dusk, when it reached $9.1 \mathrm{mg} \cdot \mathrm{dm}^{-3}(90.5 \%)$ and $8.9 \mathrm{mg} \cdot \mathrm{dm}^{-3}(81.5 \%)$, while below, to the depth of $25 \mathrm{~m}$, oxygen concentration was $7.0-8.4 \mathrm{mg} \cdot \mathrm{dm}^{-3}(50.7-$ $73.0 \%$ ), falling to $5.8 \mathrm{mg} \cdot \mathrm{dm}^{-3}(45 \%)$ at $35 \mathrm{~m}$ (Fig. 1). 


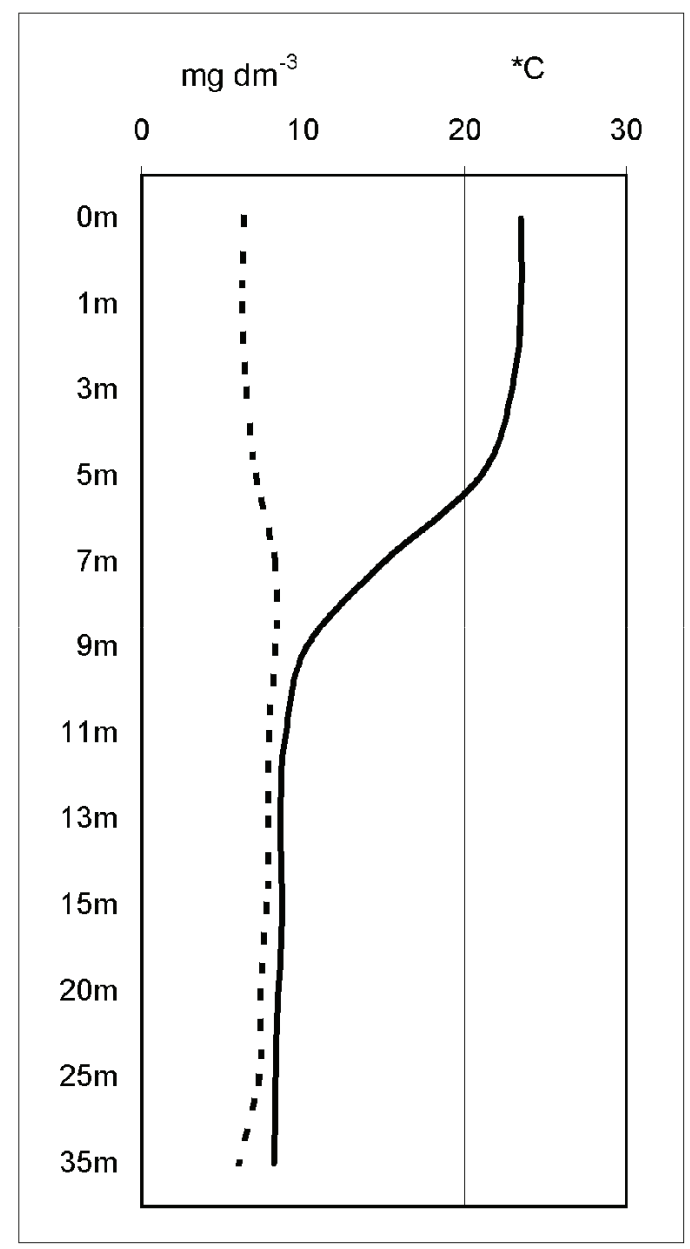

Fig. 1. Mean temperature $\left({ }^{\circ} \mathrm{C}\right.$, solid line $)$ and dissolved oxygen $\left(\mathrm{mg} \mathrm{O}_{2} \mathrm{dm}^{-3}\right.$, broken line $)$ in the vertical profile of Lake Piaseczno

Densities of the examined cladocerans ranged from about 62 ind $\cdot \mathrm{dm}^{-3}$ for $D i$ aphanosoma brachyurum to about $10 \mathrm{ind} \cdot \mathrm{dm}^{-3}$ for Bosmina longirostris. Most of the cladocerans concentrated in the upper layers of the water column: more than $70 \%$ of all individuals inhabited the layer of 0-9 $\mathrm{m}$ throughout the study period, and over $50 \%$ of the cladocerans were found in the epilimnion. Results of the Friedman test suggest that only differences in spatial distribution of all cladoceran species were highly significant (Table 1).

Diaphanosoma brachyurum, Chydorus sphaericus, and Bosmina coregoni inhabited almost exclusively the upper $7 \mathrm{~m}$ of the water column. D. brachyurum reached the highest average densities $\left(65-82 \mathrm{ind} \cdot \mathrm{dm}^{-3}\right)$ at the depth of up to 
Table 1. Results of Friedman test for the effect of depth and time on the distribution of Cladocera (shaded fields indicate highly significant differences)

\begin{tabular}{|lcccc|}
\hline & \multicolumn{2}{c}{ Spatial pattern } & \multicolumn{2}{c|}{ Temporal pattern } \\
\cline { 2 - 5 } Species & $\chi^{2}$ & $\mathrm{p}$ & $\chi^{2}$ & $\mathrm{p}$ \\
\hline Diaphanosoma brachyurum (Liévin, 1848) & 70.3 & 0.00001 & 0.53 & 0.49006 \\
Daphnia longispina O. F. Müller, 1785 & 36.6 & 0.00013 & 0.27 & 0.21163 \\
Daphnia cucullata Sars, 1862 & 26.4 & 0.00575 & 0.2 & 0.12694 \\
Bosmina coregoni Baird, 1857 & 62.2 & 0.000001 & 15.5 & 0.16211 \\
Bosmina longirostris (O. F. Müller, 1785) & 44.7 & 0.00001 & 21.4 & 0.02909 \\
Chydorus sphaericus (O. F. Müller, 1785) & 32.6 & 0.0006 & 14.1 & 0.22868 \\
\hline
\end{tabular}

$5 \mathrm{~m}$. C. sphaericus existed mostly in the lower layer, at 5-7 $\mathrm{m}$, reaching densities of 5-6 ind $\cdot \mathrm{dm}^{-3}$. B. coregoni was most abundant at $1-3 \mathrm{~m}$, with densities of $10-11$ ind $\cdot \mathrm{dm}^{-3}$. Daphnia longispina exhibited its highest densities $\left(5-10 \mathrm{ind} \cdot \mathrm{dm}^{-3}\right)$ at 5-11 m, while D. cucullata was most abundant (10-18 ind $\left.\cdot \mathrm{dm}^{-3}\right)$ within $7-11 \mathrm{~m}$ of depth. Bosmina longirostris, with the highest density at $35 \mathrm{~m}\left(28 \mathrm{ind} \cdot \mathrm{dm}^{-3}\right)$, was found only occasionally in the upper layers of the water column (Fig. 2).

MRD values for the 6 studied cladoceran species show that every species displayed clear depth selection behaviour. Among species existing in the epilimnion, Chydorus sphaericus moved during the daily cycle from $1.5 \mathrm{~m}$ to $6.5 \mathrm{~m}$, ascending at dawn and dusk, and descending during the day and night. Bosmina coregoni displayed normal vertical migration, since it occurred in the bottom part of the epilimnion during the day, and thereafter shifted to upper layers of the water column at dusk to stay there overnight. Diaphanosoma brachyurum did not display any diel vertical migration, although the species had a very clear diurnal distribution pattern, occupying from $8.2 \mathrm{~m}$ to $9.4 \mathrm{~m}$ of the water column. Although Daphnia cucullata and D. longispina were restricted mainly to upper layers of the hypolimnion, they displayed a clear vertical distribution, as they moved between $10 \mathrm{~m}$ and $15.4 \mathrm{~m}$ of depth, and what is more, their locations alternated in time. Bosmina longirostris also displayed vertical migration within the hypolimnion. The individuals migrated up to $17.5 \mathrm{~m}$ at night and stayed at greater depths (27.5-28.8 m) during daylight (Fig. 3).

\section{DISCUSSION}

It is usually accepted that the heterogeneous vertical distribution patterns of zooplankton reflect variation in food availability and predator abundance (DE STASIO 1993), including both planktivorous fish (GLIwICZ 1986, Loose \& DAwIDowicz 1994) and invertebrates (DINI \& CARPENTER 1988). MRD values suggest that cladocerans recorded in Lake Piaseczno displayed clear vertical distribution patterns. Most individuals of Chydorus sphaericus and Bosmina coregoni occurred in the epilimnion. 

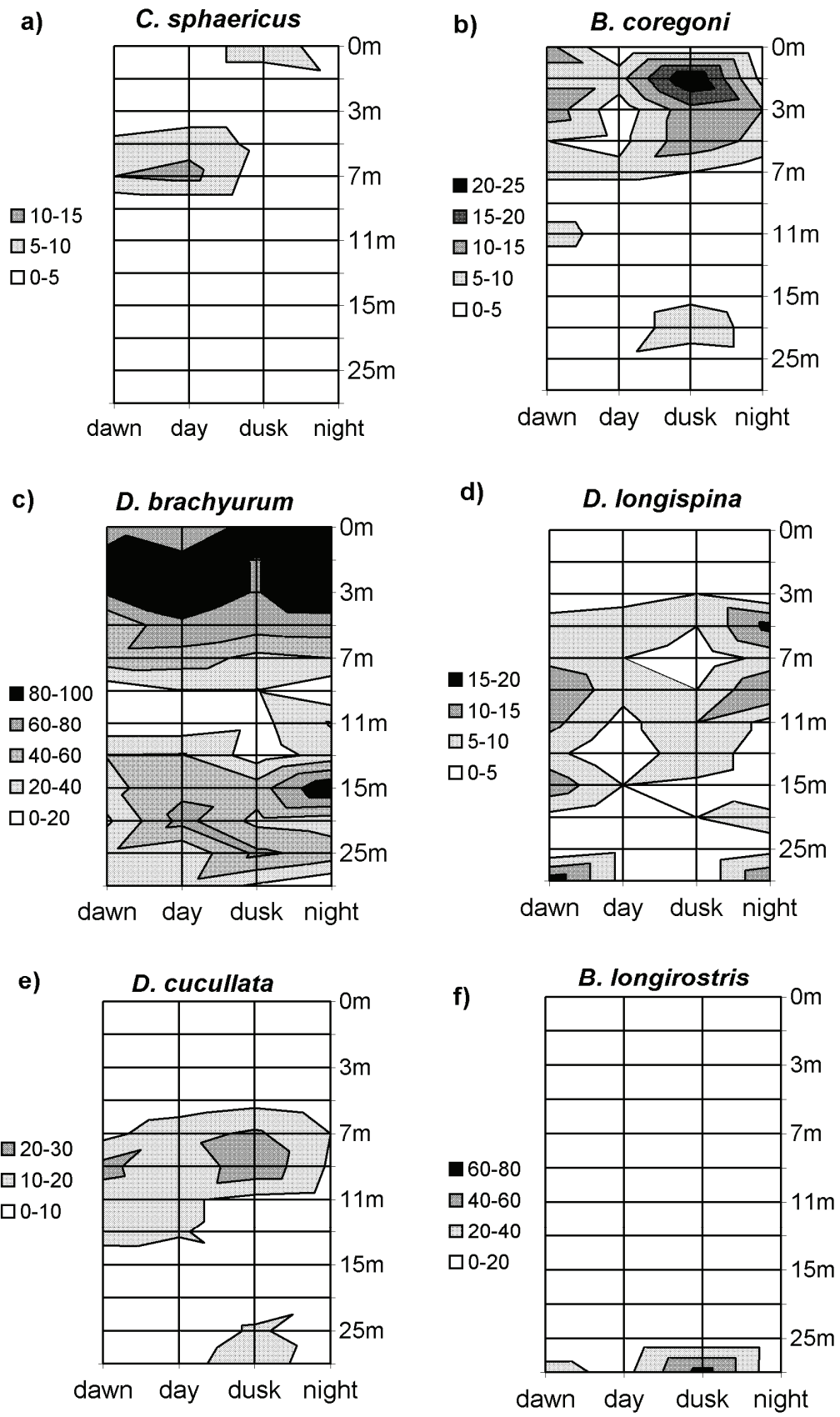

Fig. 2. Mean diel vertical distribution of Chydorus sphaericus, Bosmina coregoni, Diaphanosoma brachyurum, Daphnia longispina, D. cucullata, and B. longirostris (expressed as number of individuals per $1 \mathrm{dm}^{3}$ of water) during 3 daily cycles in July 


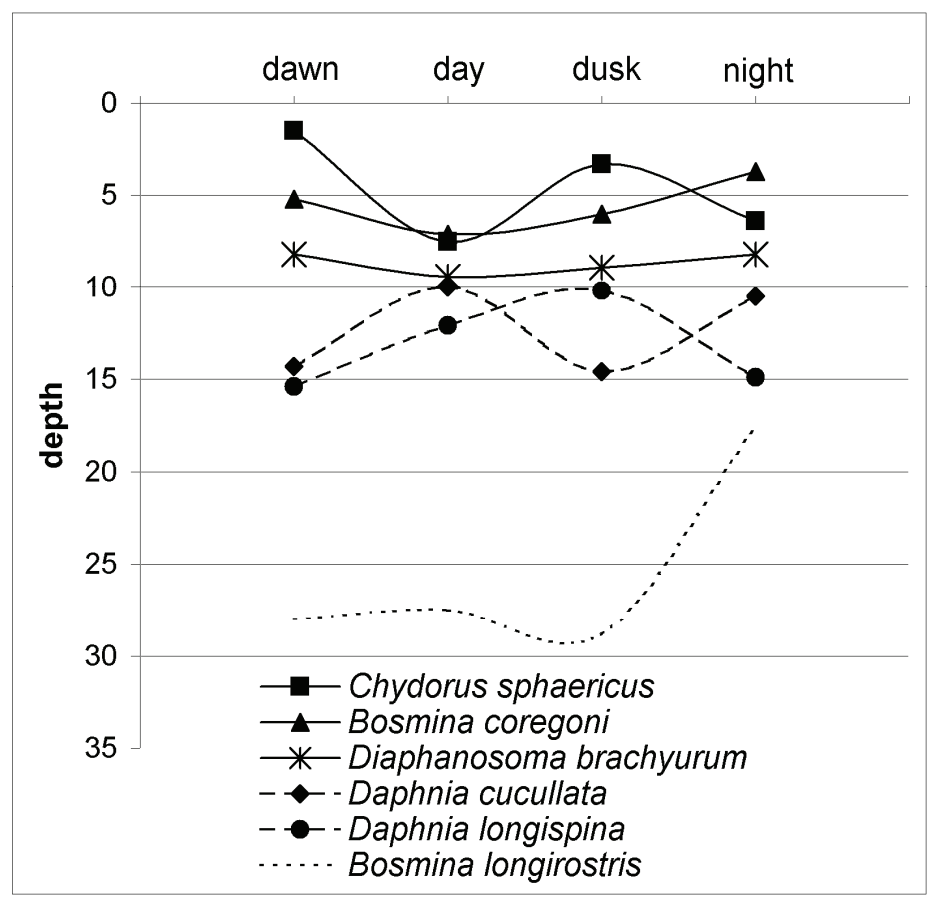

Fig. 3. Mean residence depth of the examined species

Most of Diaphanosoma brachyurum did not descend below the metalimnion. Daphnia cucullata, D. longispina, and Bosmina longirostris were found mostly in the hypolimnion, although daphnids took up the upper whilst Bosmina occupied the middle part of that thermal layer. The epi-, meta- and hypolimnion in Lake Piaseczno displayed apparent vertical gradients in temperature and oxygen capacity. Numerous studies have shown that physical and chemical gradients may create natural boundaries to reduce the mortality of cladocerans (ZAREt 1975, Shapiro 1990, Wright \& Shapiro 1990). The most important of these gradients is oxygen, as its concentration lower than $3 \mathrm{mg} \cdot \mathrm{dm}^{-3}$ is able to restrict the downward migrations by fish grazing on cladocerans (Wright \& Shapiro 1990, ThiEl et al. 1995). However, the minimum oxygen concentration in Lake Piaseczno was $5.8 \mathrm{mg} \cdot \mathrm{dm}^{-3}$, so it could not affect the vertical distribution of fish.

According to Huntley \& Brooks (1982), when food is abundant, migrations are stronger than under food limitation, so the small amplitude of migration of the cladocerans in the examined lake could be connected with food scarcity. The examined species can exploit different size ranges of food particles in every zone. Chydorus sphaericus and Bosmina species feed on smaller food particles than the remaining cladocerans. However, Chydorus sphaericus has a tendency to graze 
on the smallest particles $(<1 \mu \mathrm{m})$, and Bosmina can graze also larger ones (up to $2 \mu \mathrm{m})$. Diaphanosoma brachyurum and Daphnia spp. prefer particles with size range 1-5 $\mu \mathrm{m}$ (GLIwicz 1969). The key role of Daphnia in water bodies is attributable to their ability to filter particles in a wide range of size: from bacterioplankton to relatively large phytoplankton, therefore Daphnia is able to compete with other cladoceran species because of niche overlap. However, results of this study suggest that in Lake Piaseczno not daphnids but Diaphanosoma brachyurum was a key species, as it stayed in an optimal pelagic zone of the lake, where predation pressure is weaker compared to the epilimnion, and food abundance as well as temperature still are favourable.

Certain species apparently avoided one another, except for Daphnia species, which showed parallel trajectories in some phases of the diel cycle. The coexistence of D. cucullata and D. longispina appears to be homocompetition, i.e. competition between similar species, which, according to IVLEV (1977), is weaker than heterocompetition (competition between strongly distinguished species). Vertical distribution of Diaphanosoma brachyurum and Daphnia spp. is probably an example of heterocompetition as described by GELLER \& MÜLLER (1981) competitive exclusion between Diaphanosoma and Daphnia. Spatial distribution of Bosmina longirostris and $B$. coregoni could be expected to result from heterocompetition. Nevertheless, MATVEev`S (1985) experiments on coexistence of Bosmina spp. revealed that they do not exclude competitively one another, and their dynamics is shaped by competition with other cladocerans, like Daphnia spp. DeMott \& Kerfoot (1982) and VAnNI (1986) showed that Daphnia can depress Bosmina abundance by exploiting the preferred food source. So, in Lake Piaseczno the existence of Daphnia could determine the upper limit of $B$. longirostris ascent.

It can be supposed that fish predation pressure on Cladocera in Lake Piaseczno is substantial, since planktivorous species constitute about $90 \%$ of the total fish biomass in the lake (ADAmCZuK unupubl.). However, fish predation appeared not to account for diel vertical distribution of cladocerans, implying that competition was the major structuring force. The depth distribution of the examined species, irrespective of the strong fish predation pressure, apparently resulted from avoidance of excessive competition for food with other cladoceran species.

\section{REFERENCES}

BAYLY I.A.E. 1986. Aspects of diel vertical migration in zooplankton and its enigma variations. In: Limnology in Australia (Dedecker P., Wiliams W. D., Eds), pp. 349-368, Commonwealth Scientific and Industrial Research Organisation, Melbourne.

Cushing D. H. 1951. The vertical migration of planktonic Crustacea. Biol. Rev. 26: 158-192.

DeMott W.R., Kerfoot W.C. 1982. Competition among cladocerans: Nature of the interaction between Bosmina and Daphnia. Ecology 63: 1949-1966.

De Stasio B. 1993. Diel vertical and horizontal migration by zooplankton: population budgets and the diurnal deficit. B. Mar. Sci. 53: 44-64.

Dini M.L., Carpenter S.R. 1988. Variability in Daphnia behaviour following fish community manipulations. J. Plankton Res. 10: 621-635. 
Frost B.W., Bollens S.M. 1992. Variability of diel vertical migration in the marine planktonic copepod Pseudocalanus newmani in relation to its predators. Can. J. Fish. Aquat. Sci. 49: $1137-1141$.

Geller W., MüLler H. 1981. The filtration apparatus of Cladocera: filter mesh size and their implication on food selectivity. Oecologia 49: $316-321$.

GLiwicz Z.M. 1969. Studies on the feeding of pelagic zooplankton in lakes with varying trophy. Ekol. Pol. sec. A. 12: 663-708.

GLIwicz Z.M. 1986. Predation and evolution of vertical migration in zooplankton. Nature 320: 746-748.

Huntley M., Brooks E.R. 1982. Effects of age and food availability on diel vertical migration of Calanus pacificus. Mar. Biol. 71: 23-31.

Ivlev V.S. 1977. Experimental ecology of fish feeding. Naukova Dumka, p. 302, Kiev (in Russian).

Kitchell J.F., O`Neil R.V., Weeb D., Gallepp G.W., Bartell J.F., Koonce J.F., Ausmus B. S. 1979. Consumer regulation of nutrient cycling. Bioscience 29: 28-34.

Loose C.J., Dawidowicz P., 1994. Trade-offs in diel vertical migration by zooplankton: the costs of predator avoidance. Ecology 75: 2255-2263.

Matveev V. 1985: Competition and population time lags in Bosmina (Cladocera, Crustacea). Int. Rev. Ges. Hydrobio. 70: 491-508.

Ohman M.D. 1990. The demographic benefits of diel vertical migration by zooplankton. Ecol. Monogr. 60: 257-281.

PiJAnowsKa J., Dawidowicz P. 1987. The lack of vertical migration in Daphnia: the effect of homogeneusly distributed food. Hydrobiologia 148: 175-181.

RingelBerg J. 1999. The photobehaviour of Daphnia spp. as a model to explain diel vertical migration in zooplankton. Biol. Rev. 74: 397-423.

Ringelberg J., Flik B.J.G., LindenaAr D., Royackerrs K. 1991. Diel vertical migration of Daphnia hyalina (sensu latori) in lake Maaesseven: Part 1. Aspects of seasonal and daily timing. Arch. Hydrobiol. 121: 129-145.

Shapiro J. 1990. Biomanipulation: the next phase - making it stable. Hydrobiologia 200/201: 13-27.

Stich H.B., LAMPeRT W. 1981. Predator evasion as an explanation of diurnal vertical migration by zooplankton. Nature 293: 396-398.

Thiel R., Sepulveda A., Kafemann R., Nellen W. 1995. Environmental factors as forces structuring the fish community of the Elbe estuary. J. Fish Biol. 46: 47-69.

VANNI M. 1986. Competition in zooplankton communities: suppression of small species by Daphnia pulex. Limnol Oceanogr. 31: 1039-1056.

Wright D.I., ShaPiro J. 1990. Refuge availability: a key to understanding the summer disappearance of Daphnia. Freshwater Biol. 24: 43-62.

ZARET T.M. 1975. Strategies for existence of zooplankton prey in homogenous environments. Verh. Internat. Verein. Limnol. 19: 1484-1489. 